\title{
Integrating Information Literacy into the Science Curriculum
}

\author{
Cecelia Brown and Lee R. Krumholz
}

\begin{abstract}
A science librarian and a microbiology professor collaborated to assess information-seeking, evaluating, and usage abilities before, during, and at the end of a senior-level geomicrobiology course. ACRL's Information Literacy Competency Standards for Higher Education was used as a guide in designing a survey and checklists to measure literacy levels. Following an initial survey of the students' information literacy level, two instruction sessions were provided in the use of bibliographic finding tools available from the University of Oklahoma Libraries. During each subsequent class meeting, students presented, critiqued, and discussed a referred article. The cycle was repeated, and the survey was administered again at the end of the semester. The survey results indicated an 11 percent increase in information literacy, but no significant improvement in the students' ability to present, critique, and discuss information. A model for incorporating information literacy into upper-level undergraduate science courses and an instrument for measuring information literacy are proposed.
\end{abstract}

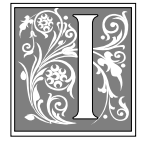

n 1989, the American Library Association's (ALA) Presidential Committee on Information Literacy defined information literacy as a set of abilities requiring individuals to locate, evaluate, and effectively use needed information. ${ }^{1}$ Information literacy not only promotes success during an individual's academic career, but it also helps him or her to subsequently be competitive in the world market and to become a lifelong learner. Achievement of information literacy has become even more challenging as society has grown increasingly dependent upon electronic communication and technologies. The 1989 ALA report gives a series of recom- mendations for fostering information literacy and encourages further investigation of methods for benchmarking information literacy abilities and progress.

Moreover, several programs for enhancing information literacy in both traditional and Web-based teaching environments have been published. ${ }^{2,3}$ Despite the importance of monitoring the success of these programs, very few studies have addressed how any improvements achieved in information literacy can be measured. ${ }^{4}$ One goal of this investigation was to devise an instrument for measuring information literacy using the Association of College and Research Libraries' (ACRL) Information Literacy Competency Standards for

Cecelia Brown is an Assistant Professor in the School of Library and Information Studies at the University of Oklahoma; e-mail: cbrown@ou.edu. Lee R. Krumholz is an Assistant Professor in the Department of Botany and Microbiology and the Institute for Energy and the Environment at the University of Oklahoma; e-mail: krumholz@ou.edu. 
Higher Education as a guide in combination with a survey previously used for the study of information literacy of physical science graduate students. ${ }^{5,6}$

Earlier studies have pointed to the importance of partnering academic librarians with faculty members to integrate information literacy programs into the general curriculum. ${ }^{7}$ A science librarian collaborated with a microbiology professor to develop an instrument to test the effectiveness of including an information literacy component in the teaching of an upper-division geomicrobiology course. The course was considered ideal for integrating an information literacy program because it requires students to use information literacy skills to find, evaluate, and present information related to a referred journal article. Consequently, a second goal of the research was to gather data to assist in the design of an information literacy program that could be easily and seamlessly incorporated into the curriculum of a range of upper-level life and physical science courses. Ultimately, utilization of such a program will advance the information literacy level of students who then will be able to find, evaluate, and use information for lifelong learning and problem-solving.

\section{Methodology}

ACRL's Information Literacy Competency Standards for Higher Education was used to design checklists to assess students' information-seeking, evaluating, and usage abilities before, during, and at the end of the geomicrobiology course. ${ }^{8}$ The five standards (shown in table 1) are further broken down into a series of performance indicators followed by several specific outcomes. For example, under Standard One, the first of four performance indicators states that the "information literate student defines and articulates the need for information." 9 Seven outcomes are then listed, including "Explores general information sources to increase familiarity with the topic" and "Identifies key concepts and terms that describe the information need." 10 The outcomes with the greatest relevance to the required tasks were used as the basis of assessment of the effectiveness of the literacy program used in this investigation.

The study population consisted of eight undergraduate and four graduate students whose ages ranged from twenty to thirty-six years, with the average being twenty-four. The students had been studying at the University of Oklahoma for an average of three and one-half years.

\begin{tabular}{|c|c|}
\hline \multicolumn{2}{|c|}{$\begin{array}{c}\text { TABLE } 1 \\
\begin{array}{c}\text { ACRL's Information Literacy Competency Standards for } \\
\text { Higher Education }\end{array} \\
\end{array}$} \\
\hline Standard One & $\begin{array}{l}\text { The information literate student determines the nature and extent } \\
\text { of the information needed. }\end{array}$ \\
\hline Standard Two & $\begin{array}{l}\text { The information literate student accesses needed information } \\
\text { effectively and efficiently. }\end{array}$ \\
\hline Standard Three & $\begin{array}{l}\text { The information literate student evaluates information and its } \\
\text { sources critically and incorporates selected information into his } \\
\text { or her knowledge base and value system. }\end{array}$ \\
\hline Standard Four & $\begin{array}{l}\text { The information literate student, individually or as a member of a } \\
\text { group, uses information effectively to accomplish a specific } \\
\text { purpose. }\end{array}$ \\
\hline Standard Five & $\begin{array}{l}\text { The information literate student understands many of the } \\
\text { economic, legal, and social issues surrounding the use of } \\
\text { information and accesses and uses information ethically and } \\
\text { legally. }\end{array}$ \\
\hline
\end{tabular}


Eight students' native language was English; one student originally spoke Korean; another, Vietnamese; and another, Chinese. One student listed both English and Spanish as his native language. After graduation, two students aspire to attend medical school, four intend to pursue a Ph.D., two desire a career as a laboratory technician, and one wants to be a high school science teacher. One other student would like to study epidemiology at the master's level, and two students do not yet have any definite career plans. The students' majors included microbiology (seven undergraduates), geology (one undergraduate), environmental chemistry (three graduate students), and natural science (one graduate student). Two microbiology majors reported pursuing a second major: one in biochemistry and one in Spanish.

Early in the semester, a questionnaire was distributed to assess the self-reported level of information literacy of the students enrolled in the class. The questionnaire was adapted from one that had been used successfully in an earlier investigation by the librarian. ${ }^{11}$ At the beginning of the term, the librarian provided detailed instruction on finding information to support the students' class assignments on two occasions. The sessions were onehour, hands-on library instruction classes in the use of bibliographic finding tools available from the University of Oklahoma Libraries. Instruction included use of the suite of databases available via OCLC's First Search, as well as Chemical Abstract Service's SciFinder Scholar and Carl UnCover.

After the library instruction sessions were completed, each subsequent class consisted of a fifty-minute lecture by the microbiology professor followed by a presentation of a referred journal article by one student. The assigned articles were published in the journals Science and Nature between 1982 and 1997 and are listed in table 2. The presenter also was instructed to perform a literature search to find two articles related to the one being presented. One article was required to be from a nonrefereed journal (popular) and another from a longer-format refereed journal. The presenter submitted a one-page discussion of the major differences between the contents and the conclusions of the three papers. Another student delivered an oral critique of the article and prepared a onepage summary of their criticisms. To stimulate discussion, two other students then asked a question about the presented article. The students submitted written copies of their questions. The faculty member graded these written and oral literacy events to evaluate the students' understanding of the material in the articles. The librarian assessed their ability to locate,

\section{Students were considered to have improved in a literacy outcome if the initial number of students with problems decreased from two or more to one or none by the end of the semester.}

evaluate, and effectively use the information in the papers using checklists based on the ACRL standards. ${ }^{12}$ Students who demonstrated competence in an information literacy skill on the checklist were given a score of one; those who did not were given a score of zero.

After every student had an opportunity to present a paper, the undergraduate students repeated the cycle and their later works were compared for differences in their information-seeking, evaluating, and usage abilities. The graduate students submitted a formal paper rather than participating in the second round of presentations, critiques, and questions. At the end of the semester, the initial questionnaire was administered again to monitor any changes in the students' level of information literacy. Students' t-tests were performed to determine whether their literacy scores significantly changed as a result of the course design. ${ }^{13}$

How often each student participated in each class session also was recorded. These data were collected to assess outcome " $1 \mathrm{a}$ " from Standard One, which suggests that an information student "confers with in- 


\section{TABLE 2}

\section{Articles Presented, Critiqued, and Questioned}

Ahmann, D., A.L. Roberts, L.R. Krumholz, and F.M.M. Morel. 1994. Microbe grows by reducing arsenic. Nature 371:750.

Alldredge, A.L., and Y. Cohen. 1987. Can microscale chemical patches persist in the sea? Microelectrode study of marine snow, fecal pellets. Science 235:689-91.

Canfield D.E., and D.J. Des Marais. 1991. Aerobic sulfate reduction in microbial mats. Science 251:1471-73.

Devol, A.H. 1991. Direct measurement of nitrogen gas fluxes from continental shelf sediments. Nature 349:319-21.

Jorgensen, B.B. 1990. A thiosulfate shunt in the sulfur cycle of marine sediments. Science 240: 152-54.

Krumholz, L.R., J.P. McKinley, G.A. Ulrich, and J.M. Suflita. 1997. Confined subsurface microbial communities in Cretaceous rock. Nature 386:64-66.

Haridon, S L., A-L. Reysenbach, P. Glenat, D. Prieur, and C. Jeanthon. 1995. Hot subterranean biosphere in a continental oil reservoir. Nature 377:223-24.

Lovley, D.R., M.J. Baedecker, D.J. Lonergan, I.M. Cozzarelli, E.J.P. Phillips, and D.I. Siegal. 1989. Oxidation of aromatic contaminants coupled to microbial iron reduction. Nature 339:297-300.

Madsen, E.L., J.L. Sinclair, and W.C. Ghiorse. 1991. In situ biodegradation: Microbiological patterns in a contaminated aquifer. Science 251:830-33.

McMahon, P.B., and F.H. Chapelle. 1991. Microbial production of organic acids in aquitard sediments and its role in aquifer geochemistry. Nature 349:233-35.

Oremland, R.S., and C.W. Culbertson. 1992. Importance of methane oxidizing bacteria in the methane budget as revealed by the use of a specific inhibitor. Nature 356:421-23.

Paerl, H.W., and R.G. Carlton. 1988. Control of nitrogen fixation by oxygen depletion in surface associated microzones. Nature 332: 260-62.

Parkes, R.J., B.A. Cragg, S.J. Bale, J.M. Getliff, and K. Goodman. 1994. Deep bacterial biosphere in pacific ocean sediments. Nature 371:410-13.

Stetter, K.O. 1982. Ultrathin mycelia-forming organisms from submarine volcanic areas having an optimum growth temperature of $105^{\circ} \mathrm{C}$. Nature $300: 258-60$.

Stevens, T.O., and J.P. McKinley. 1995. Lithoautotrophic microbial ecosystems in deep basalt aquifers. Science 270:450-55.

Vasconcelos, C., J.A. McKenzie, S. Bernasconi, D. Grujic, and A.J. Tien. 1995. Microbial mediation as a possible mechanism for natural dolomite formation at low temperatures. Nature 377:220-22. 
structors and participates in class discussions, peer workgroups, and electronic discussions to identify a research topic, or other information need." 14 In addition, qualitative comparisons were made between the first and second presentations, critiques, questions, and surveys. The students were considered competent in a specific literacy outcome if one or no students had difficulty with the outcome under scrutiny throughout the semester. Students were considered to have improved in a literacy outcome if the initial number of students with problems decreased from two or more to one or none by the end of the semester. Finally, the class was considered to have continued problems if three or more students did not exhibit the specific outcome being examined at any time during the semester.

\section{Results \\ Presentations}

Figure 1A illustrates student scores for the presentations. The scores were determined according to the students' ability to achieve specific outcomes designated by Standards Three and Four. (See table 1.) On the whole, the undergraduates fared better than the graduate students, but their scores did not improve from the first to the second presentation. In fact, the literacy scores declined significantly as indicated by a paired student's t-test at the level of $\mathrm{p}<0.1$.

Despite this lack of improvement, however, students were found to be consistently competent in several specific outcomes. With respect to Standard Three, the students were able to select the main ideas and data from the text and then to accurately restate the concepts in their own words. Competency also was exhibited in the students' ability to analyze the logic of the supporting arguments presented in the papers and to recognize interrelationships among the concepts in the papers. Moreover, the students were able to combine the concepts into meaningful statements and to support them using evidence from the papers. With regard to Standard Four, the students proved to be proficient in using information effectively to accomplish their specific purpose because they delivered well-organized and logical presentations that integrated new information with information previously learned from lectures or other papers.

Improvement was shown in two specific outcomes. In the second presentation, the students more uniformly identified and appropriately quoted material from the papers than they had in the first presentation. Also, the second presentations were more polished and practiced than the first. However, problems continued throughout the semester, primarily with outcomes from Standard Three. In Standard Three, information literacy is designated as the ability to both evaluate information sources critically and incorporate selected information into one's own knowledge base and value system. In particular, students did not place the information in the papers within any context beyond the geomicrobiology course. The investigators added an outcome as an extension of Standard Three to assess the students' ability to answer questions intelligently, clearly, and concisely. It was found that the students were ill prepared to field the questions formulated by either their fellow students or the professor.

\section{Critiques}

For the critiques of the papers, outcomes from Standards Three and Four again were used to assess the students' information literacy level. In addition, one outcome from Standard Five, the selection and consistent use of an appropriate documentation style, was examined. The students' critique scores remained constant throughout the semester as illustrated by figure $1 \mathrm{~B}$.

When critiquing a paper, students were able to recognize prejudice, manipulation, and deception. Similar to presenters, students doing a critique demonstrated the ability to recognize interrelationships among concepts and then combine them into constructive statements with supporting evidence. Throughout the semester, 


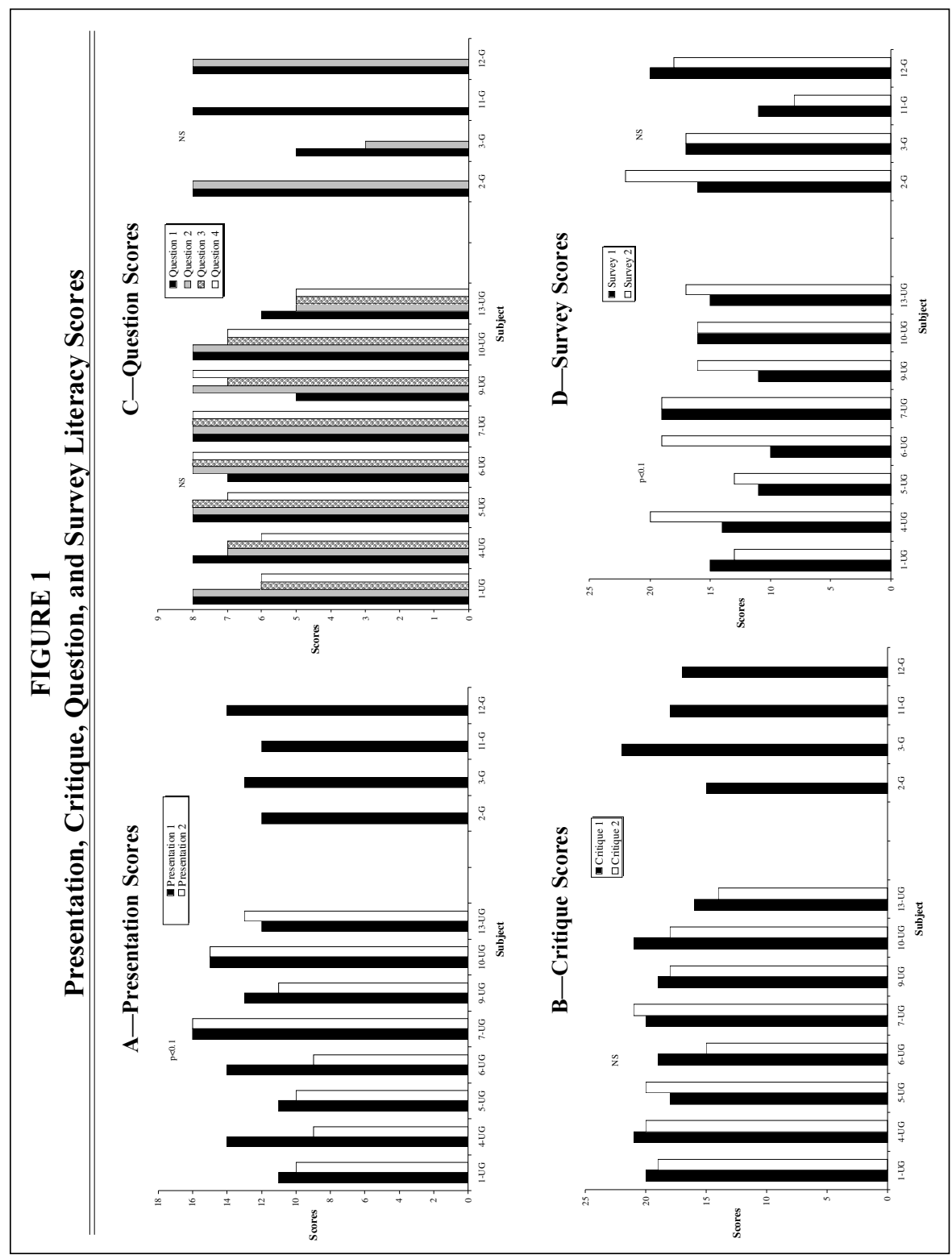

those critiquing determined the probable accuracy of the data by questioning the source and whether to incorporate or reject the viewpoints stated in the papers. Also, from the outset, these students communicated clearly in a style that was appropriate for their classroom audience.

Improvement was observed in the students' examination and comparison of information from a variety of sources in or- der to evaluate the reliability, validity, accuracy, authority, timeliness, and point of view presented in the papers. Also, the students integrated the new information from the papers with previously learned information to a greater extent in their second critiques than they had in the initial critiques.

The only continued problem highlighted by the critiques was the students' failure to select and appropriately docu- 
ment the sources cited, in particular, the paper that was subject to critique.

\section{Questions}

The undergraduate students had four opportunities to raise questions about the papers studied, and the graduate students had two. Similar to the presentations and critiques, the information literacy scores of the questions were assessed using outcomes from Standards Three and Four. Figure 1C shows that neither group of students showed a significant improvement in these scores as the semester progressed. As in the presentations and critiques, when questioning the information in the papers, the students were proficient at recognizing the interrelationships among the papers' concepts and combining them into meaningful statements with supporting evidence. Unlike those presenting a paper, questioners were able to extend the papers' initial hypotheses to a higher level of extraction. The students also consciously selected criteria from other sources to question the information given in the papers. Consistent with the competencies and improvements observed in the presentations and critiques, the questions were well organized and communicated clearly and logically in a fashion that supported the intended purposes of the class.

Although the questioners exhibited these competencies, none of the outcomes assessed were found to improve and two problems persisted. The students questioning the papers did not effectively reach conclusions based on the information in the papers nor did they consistently apply prior knowledge to the formulation of the questions asked.

\section{Surveys}

The literacy level of the undergraduate students as assessed by the self-reporting surveys improved by 11 percent over the semester. (See figure 1D.) On the other hand, the survey scores of the graduate students remained static. The competencies measured by the surveys arose from Standards One and Two, in addition to many of the outcomes previously as- sessed from Standards Three and Four. With respect to Standard One, the students were competent in determining the nature and extent of the information needed in so much as they defined or modified their requirements to achieve a manageable focus. The students also effectively described criteria used to make informed decisions and choices about the information needed to support their course work and research projects.

Standard Two focuses on accessing information effectively, and the students did indicate developing a research plan to optimize their information-searching ac-

\section{Moreover, most of them did not optimize their searching efficiency by selecting the most appropriate technologies to extract the needed information or by using tools to help them manage their information.}

tivities. The surveys showed that the students were competent in Standard Three's outcomes of determining whether the initial information need was satisfied or whether continued searching was required. Also, with respect to Standard Three, the students indicated that they reviewed information retrieval sources and searched additional sources until their information need was satisfied.

The survey responses showed improvement over the semester in several outcomes from Standard Two, including the students' understanding of the scope, content, and organization of the information retrieval systems available at the university. Moreover, by the end of the semester, the students showed improvement in their ability to assess the quantity, quality, and relevance of searching methods employed, as indicated by the wider variety of methods used. Lastly, from Standard Two, by the end of the semester more of the students had discovered methods for organizing information. Improvement in a Standard Three outcome was observed as a greater number of students indicated that they reviewed their search strategies and used additional 
concepts, as necessary, at the end of the semester than they had at the beginning.

Throughout the semester, problems persisted in several specific outcomes of Standards One and Two. Standard One suggests that an information-literate individual should explore general information sources such as encyclopedias, dictionaries, and handbooks at the outset of their information quest, but only one student carried this out. Also, from Standard One, students overall did not determine the local availability of information and decided to expand their informationseeking processes beyond local resources, if necessary. This was despite explanation at the beginning of the semester of the interlibrary loan and document delivery services available from the libraries. The majority of students elected to stop their quest for information when it could not be found locally rather than utilizing these resources. Moreover, the students did not define a timetable as indicated by Standard One but, instead, searched until they "ran out of time."

Although some progress was made in two Standard Two outcomes, students continued to have difficulty in several outcomes, thereby compromising the effectiveness of their search. Specifically, they had difficulty selecting a controlled vocabulary specific to the field of geomicrobiology as well as to the information retrieval sources searched. They also were unable to identify key words, synonyms, and related terms that would help locate information. Further, the students did not take full advantage of the technologies demonstrated to them for the retrieval of information because they did not retrieve information in a variety of formats. Moreover, most of them did not optimize their searching efficiency by selecting the most appropriate technologies to extract the needed information or by using tools to help them manage their information.

\section{Course Grades, Total Literacy Scores, and Class Participation}

Originally, it was hypothesized that the students' performance on the literacy events (presentation, critique, and questions) as assessed by the professor and their frequency of classroom participation would mirror the sum of their scores from both the checklists and the surveys. However, as illustrated by figure 2, this was not the case. The course grades on the literacy events were out of forty for the undergraduate students and out of twenty for the graduate students. The undergraduates could achieve a maximum of 150 total points for their literacy score, compared to 104 points for the graduate students. There appeared to be little relationship among the three variables for most of the students. A greater amount of variability was observed in the total literacy scores whereas the course grades achieved on the literacy events were very similar across the group.

The number of class participation events also varied, but not in concert with the literacy scores. A total of 283 class participation events were counted throughout the semester, and 54 percent of these occurred when a student acted as presenter, critiquer, or questioner. The students' reluctance to participate did not reflect their information abilities; the literacy scores were high even among those who rarely participated in class. The graduate students participated only forty-one times, or 14 percent of the total participation events counted.

One undergraduate student accounted for 48 percent of the participation events noted. This student also achieved the highest grade on the literacy events and the highest information literacy score. He is exceptional not only in his enthusiasm and ability, but also because of his intimate knowledge of, and personal interest in, geomicrobiology. He worked in the professor's lab as an undergraduate research assistant and has gone on to purse an advanced degree in microbiology at another institution.

\section{Discussion}

Incorporation of an information literacy component into a senior-level geomicrobiology course at the University of Okla- 


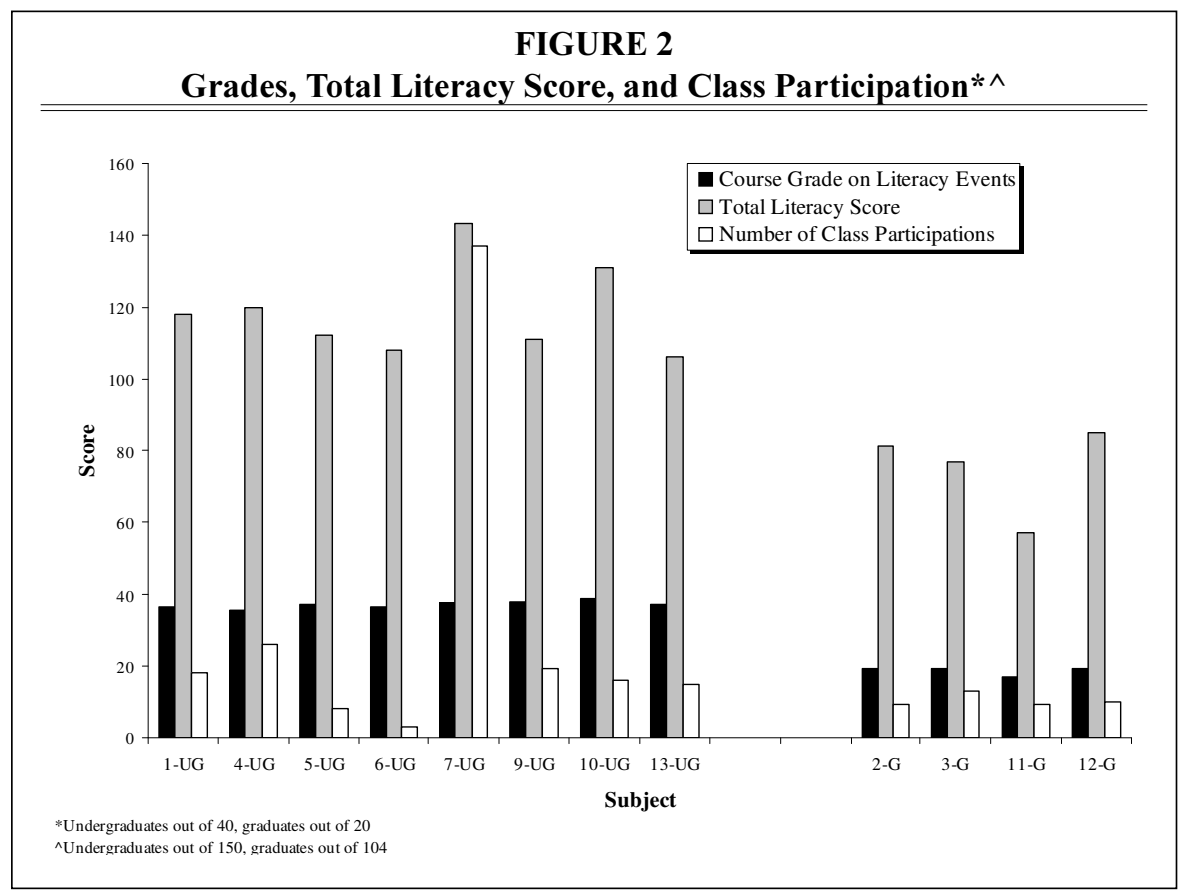

homa successfully enhanced the undergraduate students' information literacy level based on the ACRL standards when assessed using a self-reporting survey. ${ }^{15}$ However, their information literacy level was not found to significantly improve when the assessment was based on their ability to present, critique, and discuss information. The students entered the semester with competency in several information literacy outcomes as designated by the ACRL standards, especially in their ability to read a refereed journal article, extract the main ideas, and present the information gleaned in a logical fashion. ${ }^{16} \mathrm{Im}-$ provement was seen in many outcomes as a result of the course design, in particular, those outcomes that emphasize the optimal utilization of local resources. The students increased their understanding of the available information retrieval tools and consequently used a wider variety in their quests for information. However, there was room for improvement in many areas despite the library instruction sessions and the information literacy-focused course design. Although the students reported a better understanding of the available in- formation retrieval systems, they did not appear to use this knowledge to enhance their information use.

Although the students achieved high grades on the content of their presentations, critiques, and questions, their checklist results showed that they were unable "think out of the box." The students in the study did not fully answer the questions posed nor did they broaden their study beyond what the instructor required. Only the students questioning the papers extended the information to a higher level of abstraction, and only occasionally did this lead to the formulation of hypotheses different from those proposed in the paper being studied. This lack of desire to achieve a greater understanding of the material was especially evident as the semester progressed, and the presentation scores declined significantly. The decline was perhaps the result of the students becoming overburdened by course work or extracurricular activities.

Indeed, the students were very time conscious. Most of them indicated on their surveys that they would stop search- 
ing for information when they "ran out of time" rather than when their information need was met. It is likely that time constraints also were responsible for the lack of use of interlibrary loan and document delivery services, even though these would have extended and enhanced their information retrieval success significantly. To relieve some of the students' stress, future information literacy courses could incorporate a time management component to help students plan, implement, and document their information searches. Students then may have more time to draw on past knowledge and to stretch their thinking beyond the information presented in the assigned papers.

It also is possible that the students' lack of motivation and inclination to achieve a greater understanding of the material was due to complacency with the grade achieved on their first assignments. In their research, Honora F. Nerz and Suzanne T. Weiner noted that grades are powerful motivators for engineering students who "become masters at being able to do the minimum amount of work for the maximum grade available."17 Similarly, Barbara Valentine found that humanities and social science undergraduate students were so highly propelled by grades that they spent an enormous amount of energy trying to find out what the professor wanted rather than concentrating on the course material. ${ }^{18}$

In this study, lack of motivation was accompanied by infrequent participation in classroom discussions. It was especially troublesome for the investigators to observe the graduate students, who were expected to be the more mature, experienced, and confident members of the group, contribute only 14 percent of the total participation events recorded. Students participated primarily when they were involved in a literacy event (i.e., presenting, critiquing, or questioning). Otherwise, they relied on the questioners, the professor, and the one enthusiastic student to stimulate the discussion. Currently, the professor is using the same course design but is requiring all students to formulate and hand in a question every day. Two students are randomly selected to pose their questions to the class. The professor is finding that not only has individual class participation increased, but he is also gaining a better understanding of the students' grasp of the concepts in the papers. Moreover, the class size is larger this semester (twenty undergraduate and five graduate students), which may contribute to the increased class participation.

Other methods to stimulate heightened interest in the course material and to increase involvement in the classroom discussions would be to include breakout sessions inside or outside the class period, where students are required to formulate questions together and raise them as a group. Some students may perceive such a peer-centered environment to be less threatening and thus may participate to a greater extent than they do in the more public forum of the classroom. ${ }^{19}$ Another way to increase student involvement would be to set up one-on-one meetings with the instructor to discuss the paper or other topics of concern prior to the students' presentations. Students also could meet individually with the librarian to discuss specific information-seeking queries. ${ }^{20}$ Commitment on the part of the instructor and the librarian to individualized instruction may encourage the students to give more of themselves to the learning process. Also, building confidence in individualized fashions, outside the more public arena of the classroom, may allow students to feel more at ease and thus better able to participate in class.

The surveys also indicated that several of the students were unwilling to improve their methods of information retrieval. Although their selection was broadened, the databases were searched with a limited selection of terms despite detailed library instruction. Better use of the tools available and retrieval methods may be achieved by scattering the library instruction sessions throughout the semester, in smaller doses when it may be more relevant to the students' information needs, rather than at the beginning of the semes- 
ter. This could be used in conjunction with the current design by adding self-paced Web-based tutorials and/or by electronically mounting Power Point slides or videos of the initial presentations for the students to refer to when necessary.

Another troubling discovery was the inconsistent-and frequently nonexistent-documentation of the sources used in the presentations, questions, and critiques. The students cited neither the paper studied in their written assignments nor any additional sources read. Apparently, students do not find it necessary to cite the resources used. Thus, any further information literacy education should focus on the importance of correctly and thoroughly referencing material used in course work.

Many studies have touted the importance of the faculty-librarian partnership in ensuring the success of an information literacy program..$^{21}$ Indeed, the partnership between professor and librarian was instrumental in effecting, implementing, and evaluating the design of the course. When evaluating the students, the professor found that they performed consistently well in all the literacy events and in the course as a whole whereas the librarian found greater variability in the their information literacy based on the ACRL standards. ${ }^{22}$ In fact, achievement on the literacy events bore little resemblance to the students' ability to demonstrate specific literacy outcomes. Because it is apparent that the students are capable of producing a good product, despite variability in information literacy competency, the specific outcomes the librarian was looking for might be unrealistic. Since this study was conducted, the ACRL Instruction Section (IS) has developed a set of more practical objectives. ${ }^{23}$ Use of the IS objectives may have resulted in closer correlation between the instructor's grades on the literacy events and the literacy scores calculated by the librarian.

\section{Conclusions}

This investigation presents a design for incorporating information literacy into a senior-level science course. The students reported themselves to have enhanced information-seeking abilities as a result of the course design in which library instruction is paired with critical analysis of the research literature. However, this perceived enhancement was not reflected in a significantly improved ability to use information. Future research to optimize both the retrieval and use of information should include instruction in time management and documentation of sources consulted. Information education should include explicit details about the accessibility of external resources as well as the nuances of key word and subject searching. Greater strides in information literacy development also may be achieved by restructuring the timing of the library instruction so that the sessions are shorter, more frequent, and scattered throughout the semester. Moreover, materials should be available on the Web to support the library instruction sessions. Individual sessions with the instructor and the librarian are recommended to boost the students' confidence in their grasp of the material and information-seeking skills. Further, group sessions would provide students with the opportunity to formulate questions in a less threatening, peercentered environment.

The study also suggests an instrument for measuring information literacy based on several of the specific outcomes from ACRL's Information Literacy Competency Standards. ${ }^{24}$ ACRL's more recently developed literacy objectives are more practical in nature than those used and thus are likely to prove useful in improving the instrument employed. ${ }^{25}$ Also, a Lickert, rather than a binary, scale should be used to better discern the subtle differences among the students. Finally, testing the design with a larger class size or with several science classes would be helpful in illuminating the influence of library instruction on the information literacy of science students.

This type of research promoting information literacy is critical to foster the literacy level of students who, ultimately, will 
become critical thinkers and lifelong learners and thereby well equipped to succeed in the work force and contribute positively to society.

\section{Notes}

1. American Library Association, Presidential Committee on Information Literacy, Final Report (Chicago: ALA, 1989), 1.

2. Chris Atton, "Using Critical Thinking as a Basis for Library User Education," Journal of Academic Librarianship 20 (Nov. 1994): 310-13; Patricia Senn Brevick and Dan L. Jones, "Information Literacy: Liberal Education for the Information Age," Liberal Education 79 (winter 1991): 2429; Christine Bruce, "Information Literacy Programs and Research: An International Review," Australian Library Journal 49 (Aug. 2000): 209-18; Christine Susan Bruce, "Information Literacy: A Framework for Higher Education," Australian Library Journal 44 (Aug. 1995): 158-70; Susan Carol Curzon, "Developing a Program of Information Literacy: How California State University Did It," College E Research Libraries News 61 (June 2000): 483-86; Zorana Ercegovac, "Information Literacy: Teaching Now for Year 2000," Reference Services Review 26 (fall/winter 1998): 139-60; Katherine Furlong and Franklin D. Roberts, "If You Teach It, Will They Learn? Information Literacy and Reference Services in a College Library," Computers in Libraries 18 (May 1998): 22-25; Tina Evans Greenwood and Jeffrey Frisbie, "Library Instruction That's Out of This World! Information Literacy at Fort Lewis College," Reference Services Review 26 (fall/winter 1998): 45-50; Loanne Snavely and Natasha Cooper, "Competing Agendas in Higher Education: Finding a Place for Information Literacy," Reference \& User Services Quarterly 37 (fall 1997): 53-62; Laura A. Sullivan and Nancy F. Campbell, "Strengthening the Foundation for Information Literacy in an Academic Library," Reference Librarian 33 (1991): 183-89; Sheila Webber and Bill Johnson, "Conceptions of Information Literacy: New Perspectives and Implications," Journal of Information Science 26 (2000): 381-96; Richard Hume Werking, "A Critical Look at Possibilities for and Obstacles to Library Use," RQ 31 (winter 1991): 162-66; Herbert S. White, "Bibliographic Instruction, Information Literacy, and Information Empowerment," Library Journal 117 (Jan. 1992): 78-79; Terrence E. Young, “The Big Three Information Literacy Models," Knowledge Quest 27 (Jan.-Feb. 1999): 32-35.

3. Mark Jacobs, "Speakeasy Studio and Café: Information Literacy, Web-based Library Instruction, and Technology," Information Technology and Libraries 20 (June 2001): 66-71; Kimberly B. Kelley, Gloria J. Orr, Janice Houck, and Claudine SchWeber, "Library Instruction for the Next Millennium: Two Web-based Courses to Teach Distance Students Information Literacy," Journal of Library Administration 32 (2001): 281-94; Kate Manuel, "Teaching an Online Information Literacy Course," Reference Services Review 29 (2001): 219-28; Paul Nieuwenhuysen, "Information Literacy Courses for University Students: Some Experiments and Some Experience," CampusWide Information Systems 17 (2000): 167-73; Pierina Parise, "Information Power Goes Online: Teaching Information Literacy to Distance Learners," Reference Services Review 26 (fall/winter 1998): 51-60; Gay Tierney, "Information Literacy Skills for Distance Education Students," Access 13 (Aug. 1999): 36-38.

4. Cecelia M. Brown, "Information Literacy of Physical Science Graduate Students in the Information Age," College \& Research Libraries 60 (spring 1999): 426-38; Patricia Iannuzzi, "We Are Teaching, But Are They Learning: Accountability, Productivity, and Assessment," Journal of Academic Librarianship 25 (July 1999): 304-5; Karin de Jager and Mary Nassimbeni, "Roadmaps for the Highway: The Evaluation of an Information Literacy Training Programme for South African Students," Education for Information 16 (1998): 131-43; Patricia Davitt Maughan, "Assessing Information Literacy among Undergraduates: A Discussion of the Literature and the University of California-Berkeley Assessment Experience," College \& Research Libraries 62 (Jan. 2001): 71-85.

5. Association of College \& Research Libraries, Information Literacy Competency Standards for Higher Education (Chicago: ACRL, 2000). Available online from http://www.ala.org/acrl/ ilcomstan.html.

6. Brown, "Information Literacy of Physical Science Graduate Students," 426-38.

7. Donna Amstutz and Donna Whitson, "University Faculty and Information Literacy: Who Teaches the Students?" Research Strategies 15 (winter 1997): 18-25; Katherine Beaty Chiste, Andrea Glover, and Glenna Westwood, "Infiltration and Entrenchment: Capturing and Securing Information Literacy Territory in Academe," Journal of Academic Librarianship 26 (May 2000): 2028; Christine Bruce, "Faculty-Librarian Partnerships in Australian Higher Education: Critical Dimensions," Reference Services Review 29 (2001): 106-15; Nancy Dennis, "Using Inquiry Methods to Foster Information Literacy Partnerships," Reference Services Review 29 (2001): 122-31; Elizabeth A. Dupuis, "The Information Literacy Challenge: Addressing the Changing Needs of Our Students through Our Programs," Internet Reference Services Quarterly 2 (1997): 93-111; Violet Harada and Ann Tepe, "Pathways to Knowledge," Teacher Librarian 26 (Nov.-Dec. 1998): 9-15; Carla 
Higgins and Mary Jane Cedar Face, "Integrating Information Literacy Skills into the University Colloquium: Innovation at Southern Oregon University," Reference Services Review 26 (fall/winter 1998): 17-32; Patricia Iannuzzi, "Faculty Development and Information Literacy: Establishing Campus Partnerships," Reference Services Review 26 (fall/winter 1998): 97-116; Denise Isbell and Carol Hammond, "Information Literacy Competencies," College $\mathcal{E}$ Research Library News 6 (June 1993): 325-27; Gloria J. Leckie and Anne Fullerton, "Information Literacy in Science and Engineering Undergraduate Education: Faculty Attitudes and Pedagogical Practices," College $\mathcal{E}$ Research Libraries 60 (Jan. 1990): 9-29; J. Edmund Maynard, "A Case Study of Faculty Attitudes toward Library Instruction: The Citadel Experience," Reference Services Review 18 (summer 1990): 67-76; Lawrence J. McCrank, "Academic Programs for Information Literacy: Theory and Structure," RQ 31 (summer 1992): 485-97; Honora F. Nerz and Suzanne T. Weiner, "Information Competencies: A Strategic Approach," 2001 ASEE Conference Proceedings (Washington, D.C.: American Society of Engineering Education, 2001), available online from http://www.asee.org/conferences/annual2001/bestpapers.cfm; Glenn Ellen Starr and Paul Gaskill, “The Community Study Assignment for Leisure Studies: Integrating Information Literacy, Leisure Theory, and Critical Thinking," Research Strategies 15 (1997): 205-16.

8. ACRL, Information Literacy Competency Standards.

9. Ibid., 9 .

10. Ibid.

11. Brown, "Information Literacy of Physical Science Graduate Students."

12. ACRL, Information Literacy Competency Standards.

13. Robert M. Losee Jr. and Karen A. Worley, Research and Evaluation for Information Professionals (San Diego, Calif.: Academic Pr., 1993), 183-86.

14. ACRL, Information Literacy Competency Standards, 8.

15. ACRL, Information Literacy Competency Standards.

16. Ibid.

17. Nerz and Weiner, "Information Competencies."

18. Barbara Valentine, "The Legitimate Effort in Research Papers: Student Commitment versus Faculty Expectations," Journal of Academic Librarianship 27 (Mar. 2001): 107-15.

19. Atton, "Using Critical Thinking as a Basis for Library User Education."

20. Valentine, "The Legitimate Effort in Research Papers."

21. Amstutz and Whitson, "University Faculty and Information Literacy"; Beaty Chiste, Glover, and Westwood, "Infiltration and Entrenchment"; Bruce, "Faculty-Librarian Partnerships in Australian Higher Education"; Dennis, "Using Inquiry Methods to Foster Information Literacy Partnerships"; Dupuis, "The Information Literacy Challenge"; Harada and Tepe, "Pathways to Knowledge"; Higgins and Face, "Integrating Information Literacy Skills into the University Colloquium"; Iannuzzi, "Faculty Development and Information Literacy"; Isbell and Hammond, "Information Literacy Competencies"; Leckie and Fullerton, "Information Literacy in Science and Engineering Undergraduate Education"; Maynard, "A Case Study of Faculty Attitudes toward Library Instruction"; McCrank, "Academic Programs for Information Literacy"; Nerz and Weiner, "Information Competencies"; Starr and Gaskill, "The Community Study Assignment for Leisure Studies."

22. ACRL, Information Literacy Competency Standards.

23. ACRL Instruction Section, "Objectives for Information Literacy: A Model Statement for Academic Librarians," College $\mathcal{E}$ Research Libraries News 62 (Apr. 2001): 416-28.

24. ACRL, Information Literacy Competency Standards.

25. ACRL Instruction Section, "Objectives for Information Literacy." 